\title{
IS BURNOUT IN FAMILY PHYSICIANS IN CROATIA RELATED TO INTERPERSONAL QUALITY OF CARE?
}

\author{
Zlata OŽVAČIĆ ADŽIĆ ${ }^{1}$, Milica KATIĆ ${ }^{1}$, Josipa KERN², Jean Karl SOLER ${ }^{3}$, \\ Venija CEROVEČKI ${ }^{1}$, and Ozren POLAŠEK ${ }^{4}$ \\ Department of Family Medicine', Department of Medical Statistics, Epidemiology and Medical Informatics', \\ University of Zagreb, School of Medicine, “Andrija Štampar” School of Public Health, Zagreb, Croatia, \\ Mediterranean Institute of Primary Care, Attard ${ }^{3}$, Malta, University of Split, School of Medicine, Department of Public \\ Health, Split ${ }^{4}$ Croatia \\ Received in September 2012 \\ CrossChecked in September 2012 \\ Accepted in January 2013
}

\begin{abstract}
The impact of physician burnout on the quality of patient care is unclear. This cross-sectional study aimed to investigate the prevalence of burnout in family physicians in Croatia and its association with physician and practice characteristics, and patient enablement as a consultation outcome measure.

Hundred and twenty-five out of 350 family physicians responded to our invitation to participate in the study. They were asked to collect data from 50 consecutive consultations with their adult patients who had to provide information on patient enablement (Patient Enablement Instrument). Physicians themselves provided their demographic and professional data, including workload, job satisfaction, consultation length, and burnout [Maslach Burnout Inventory - Human Services Survey (MBI-HSS )]. MBI-HSS scores were analysed in three dimensions: emotional exhaustion (EE), depersonalisation (DP), and personal accomplishment (PA).

Of the responding physicians, $42.4 \%$ scored high for EE burnout, $16.0 \%$ for DP, and $15.2 \%$ for PA. Multiple regression analysis showed that low job satisfaction and more patients per day predicted high EE scores. Low job satisfaction, working more years at a current workplace, and younger age predicted high DP scores. Lack of engagement in education and academic work, shorter consultations, and working more years at current workplace predicted low PA scores, respectively $(P<0.05$ for each).

Burnout is common among family physicians in Croatia yet burnout in our physicians was not associated with patient enablement, suggesting that it did not affect the quality of interpersonal care. Job satisfaction, participation in educational or academic activities and sufficient consultation time seem to reduce the likelihood of burnout.
\end{abstract}

KEY WORDS: family practice, patient enablement, quality of health care

Burnout is a psychological syndrome developed in response to exposure to continuing interpersonal stressors, usually in jobs involving intense interaction with people. Burnout is characterised by feelings of emotional exhaustion (emotional overextension and depletion of own emotional resources), depersonalisation (negative feelings and attitudes toward clients) and reduced sense of personal accomplishment (negative self-evaluation in terms of productivity at work) $(1,2)$. It is a personal experience related more to situational factors (e.g. workload, time 
pressure, role conflict; job resources: social support, autonomy, and decision involvement) than to individual factors (e.g. demographic and personality characteristics, work-related attitudes) (2) and is significantly determined by the (in)congruence between personal values and values inherent to the health care system (3).

The complex nature of providing accessible, continuing, and comprehensive care to patients and their families and managing ethical dilemmas, puts family physicians at high risk of depletion of their emotional resources and developing burnout $(3,4)$. The reported prevalence of burnout in family physicians and family medicine trainees in the last decades is disconcerting (5-10). The EGPRN Burnout study reports emotional exhaustion in $43 \%$, depersonalisation in $35 \%$, and feelings of reduced personal accomplishment in $32 \%$ of family physicians across Europe (11).

Physician burnout may affect physicians' own well-being and their practice $(1,2)$. However, this impact on the quality of care is still not clear. Studies with medical residents have reported an association between high burnout levels and the number of selfperceived medical errors (12) or self-reported suboptimal patient care (13). However, they have not revealed any association between burnout and objective measures of medical error (14).

Limited information is available about how physician burnout is related to interpersonal quality of care - one of the key elements in defining quality of care according to Campbell (15) and a core attribute of good general practice (16). Earlier studies find no significant association between physician burnout and patient satisfaction, patient ratings of physician's interpersonal skills, or observed patient-centredness during primary care consultations $(17,18)$.

To our knowledge, no study has examined the relationship between physician burnout and patient enablement, a patient-reported consultation outcome measure that reflects the extent to which patients understand and feel able to cope with their life and

Table 1 Distribution of physicians by demographic characteristics, professional characteristics, and job satisfaction $(\mathrm{N}=125)$

\begin{tabular}{lcc}
\hline Characteristic & $\boldsymbol{N}$ & $\mathbf{\%}$ \\
\hline Sex & 23 & 18.4 \\
Male & 102 & 81.6 \\
Female & & \\
\hline Marital status & 100 & 80.0 \\
Married & 15 & 12.0 \\
Single & 8 & 6.4 \\
Divorced/separated & 2 & 1.6 \\
Widowed & & \\
\hline Children & 105 & 84.0 \\
Yes & 20 & 16.0 \\
No & & \\
\hline Education and/or academic work & 24 & 19.2 \\
Yes & 101 & 80.8 \\
No & & \\
\hline Type of work & 11 & 8.8 \\
State employed & 99 & 79.2 \\
Private practice, leased & 15 & 12.0 \\
Private practice, owned & & \\
\hline Job satisfaction & 7 & 5.6 \\
0 (low) & 1 & 0.8 \\
1 & 6 & 4.8 \\
2 & 26 & 20.8 \\
3 & 50 & 40.0 \\
4 & 18 & 14.4 \\
5 & 17 & 13.6 \\
6 (high) & & \\
& & \\
\hline
\end{tabular}


illness as a result of general practice consultation (16) The aim of our study was therefore to investigate the prevalence of burnout in family physicians in Croatia and see if it was associated with physician and practice characteristics and patient enablement.

\section{PARTICIPANTS AND METHODS}

\section{Participants}

This cross-sectional study was conducted as part of two concurrent research projects: Evidence-Based Quality of Health Care, funded by the Croatian Ministry of Science, Education and Sports, and the European General Practice Research Network (EGPRN) Burnout Study (11). It was approved by the Ethics Committee of the Zagreb University School of Medicine.

From the target population of 2418 physicians working in the family medicine service in Croatia (19) we contacted a random sample of 350 physicians using a multistage, stratified, proportional sample design for their selection. Five stratification criteria on which we based this selection included physician's age $[\leq 34$ years, (35 to 54 ) years, $\geq 55$ years], sex, vocational training (medical doctor without specialisation, general practice / family medicine specialist, occupational health specialist, school medicine specialist), practice size $[\leq 1200$ patients, (1201 to 1699) patients, $\geq 1700$ patients], and geographical distribution of the practices (21 Croatian counties). These data were taken from the Croatian National Institute of Public Health (19) and the Croatian Institute of Health Insurance.

The physicians were asked to complete two selfadministered, anonymous questionnaires and to pass the third questionnaire to 50 patients aged $\geq 18$ years as they came for a consultation. Patients were informed about the purpose of the study, and about the anonymous and voluntary nature of participation.

Physicians were also asked to time each consultation with a watch, and round its length to the nearest halfminute. Patients were asked to fill out the questionnaire immediately after the consultation and leave it in a sealed box at the reception desk to ensure confidentiality.

\section{Questionnaires}

The first questionnaire for physicians included demographic data, educational/academic engagement (teaching medical students, interns, or trainees and/or scientific research), type of employment (stateemployed or self-employed, the second further divided

Table 2 Frequency distribution of responding physicians by degree of burnout (high, average, low) in three burnout dimensions $(\mathrm{N}=125)$

\begin{tabular}{lcccccc}
\hline \multirow{2}{*}{ Burnout } & \multicolumn{2}{c}{ Emotional exhaustion } & \multicolumn{2}{c}{ Depersonalisation } & \multicolumn{2}{c}{ Personal accomplishment } \\
\cline { 2 - 7 } & $\boldsymbol{N}$ & $\mathbf{\%}$ & $\boldsymbol{N}$ & $\mathbf{\%}$ & $\boldsymbol{N}$ & $\mathbf{\%}$ \\
\hline High & 53 & 42.4 & 20 & 16.0 & 19 & 15.2 \\
\hline Moderate & 32 & 25.6 & 29 & 23.2 & 31 & 24.8 \\
\hline Low & 40 & 32.0 & 76 & 60.8 & 75 & 60.0 \\
\hline
\end{tabular}

Table 3 Correlation between physician characteristics and EE, DP, or PA scores

\begin{tabular}{lccccccc}
\hline Age & $\begin{array}{c}\text { Years working } \\
\text { at current } \\
\text { workplace }\end{array}$ & $\begin{array}{c}\text { Average } \\
\text { number of } \\
\text { patients per } \\
\text { day }\end{array}$ & $\begin{array}{c}\text { Average } \\
\text { number of } \\
\text { house calls } \\
\text { per week }\end{array}$ & $\begin{array}{c}\text { Job } \\
\text { satisfaction }\end{array}$ & $\begin{array}{c}\text { Mean } \\
\text { physician-specific } \\
\text { patient } \\
\text { enablement score }\end{array}$ & $\begin{array}{c}\text { Mean } \\
\text { phsician- } \\
\text { specific } \\
\text { consultation } \\
\text { length }\end{array}$ \\
\hline $\begin{array}{l}\text { EE } \\
\text { score }\end{array}$ & -0.110 & -0.037 & $0.182^{*}$ & 0.108 & $-0.575^{*}$ & 0.012 & -0.003 \\
\hline $\begin{array}{l}\text { DP } \\
\text { score }\end{array}$ & -0.084 & 0.062 & 0.073 & 0.082 & $-0.198^{*}$ & -0.121 & -0.159 \\
\hline $\begin{array}{l}\text { PA } \\
\text { score }\end{array}$ & 0.047 & -0.101 & 0.090 & 0.064 & $0.253^{*}$ & -0.037 & $0.178^{*}$ \\
\hline
\end{tabular}

EE - emotional exhaustion; DP - depersonalisation; $P A$ - personal accomplishment Spearman rank order correlation coefficients ${ }^{*} p<0.05$ 
into leased or owned private practice), and workload. It was originally designed for a national study described elsewhere (20).

The second questionnaire for physicians was designed by the EGPRN Burnout Study Group (11). It incorporated demographic data, working experience, job satisfaction, and the Maslach Burnout Inventory - Human Services Survey (MBI-HSS). MBI-HSS is a standardised instrument that measures burnout in healthcare professionals (1). It consists of 22 Likerttype questions in which physicians score how often they find a statement (item) applicable to them (on a 7-point scale ranging from $0=$ "never" to $6=$ "every day"). The scoring covers three dimensions: emotional exhaustion (EE), depersonalisation (DP), and personal accomplishment (PA) as follows: EE subscale has nine items and a maximum score of 54, DP has five items and a maximum score of 30 , and PA has eight items and a maximum score of 48. High EE or DP scores and low PA scores indicate high levels of burnout. The EGPRN Burnout questionnaire was translated into Croatian according to a method adopted by the EGPRN Burnout Study Group and tested in an international validation pilot study (21). No adaptations of the questionnaire were necessary after the pilot. The MBI-HSS section of the questionnaire was internally validated during the EGPRN Burnout study in European family doctors by calculating Cronbach's alpha coefficient for each dimension (EE, DP, and PA). For the Croatian translation of the questionnaire
Cronbach's alpha was 0.92 for EE dimension, 0.73 for DP dimension, and 0.77 for PA dimension (11).

Our analysis combined variables from both questionnaires, including physician's age (years), sex, marital status (married, single, divorced/separated, widowed), children (yes/no), educational/academic engagement (yes/no), type of employment (state or self-employed), years in current position, average number of patients per day, average number of house calls per week, job satisfaction (7-point Likert-type scale, ranging from $0=$ "very little" to $6=$ "very much"), EE, DP, and PA score.

Patients completed a self-administered questionnaire that included a standardised Patient Enablement Instrument (PEI) developed to measure enablement at consultations (22). PEI includes six items addressing patients' ability to understand their illness, to cope with their illness after seeing the doctor, and addressing the degree to which they feel to be able to cope with life, keep themselves healthy, feel confident about their health, and help themselves (22). Responses "much better", "better", and "same or less" were scored 2, 1, and 0, respectively. The PEI questionnaire was translated into Croatian separately by two researchers and validated at a discussion group with other researchers, an English teacher employed atZagreb Medical School, and 10 patient representatives of different age, sex, and educational level. No adaptations of the questionnaire were necessary. The questionnaire was then translated back into English

Table 4 Multiple regression analysis using overall scores of the three burnout dimensions as dependent variable

\begin{tabular}{|c|c|c|c|c|c|c|}
\hline & \multicolumn{2}{|c|}{$\mathbf{E E *}$} & \multicolumn{2}{|c|}{ DP** } & \multicolumn{2}{|c|}{$\mathbf{P A} * * *$} \\
\hline & Beta & $P$ & Beta & $P$ & Beta & $P$ \\
\hline Intercept & 40.868 & 0.002 & 11.892 & 0.043 & 35.829 & $<0.0001$ \\
\hline Age & -0.223 & 0.226 & -0.171 & 0.041 & 0.190 & 0.063 \\
\hline Sex $(1=$ male, $2=$ female $)$ & 2.607 & 0.312 & 1.597 & 0.171 & 0.199 & 0.889 \\
\hline Marital status $(1=$ married, $2=$ other $)$ & -1.606 & 0.574 & -0.301 & 0.816 & -1.182 & 0.456 \\
\hline Children $(1=$ yes, $2=$ no $)$ & -1.447 & 0.664 & 0.510 & 0.735 & -1.315 & 0.478 \\
\hline Educational/academic work ( $1=$ yes, $2=$ no $)$ & 0.314 & 0.899 & 1.489 & 0.182 & -3.537 & 0.011 \\
\hline Type of work ( $1=$ private, $2=$ public $)$ & -3.886 & 0.256 & -1.955 & 0.206 & 2.570 & 0.176 \\
\hline Years working at current workplace & 0.101 & 0.175 & 0.181 & 0.023 & -0.280 & 0.005 \\
\hline Average number of patients per day & 0.245 & 0.014 & 0.036 & 0.416 & -0.003 & 0.958 \\
\hline Average number of house calls per week & 0.126 & 0.265 & -0.086 & 0.474 & 0.154 & 0.297 \\
\hline Job satisfaction & -4.746 & $<0.0001$ & -0.561 & 0.042 & 0.515 & 0.151 \\
\hline Mean physician-specific consultation length & 0.465 & 0.108 & -0.173 & 0.185 & 0.447 & 0.006 \\
\hline Mean physician-specific patient enablement score & -0.675 & 0.382 & -0.346 & 0.323 & -0.339 & 0.429 \\
\hline
\end{tabular}

EE - emotional exhaustion; DP - depersonalisation; $P A$ - personal accomplishment

$*$ EE model: Sum of squares $=6920.710, d f=12, \mathrm{P}<0.0001, R 2=0.384$

$* * D P$ model: Sum of squares $=878.170, d f=12, \mathrm{P}=0.011, R 2=0.143$

$* * * P A$ model: Sum of squares $=833.274, d f=12, \mathrm{P}=0.013, R 2=0.196$ 
by another researcher and the translation was compared with the original (20).

All questionnaires were sent to physicians by mail together with a cover letter and a prepaid reply envelope. No financial or educational incentives were provided to participating physicians. After one month they received a reminder.

\section{Statistical analysis}

For analysis we used descriptive statistics. MBIHSS scores were calculated for EE, DP, and PA and then transformed into categorical variables for high, moderate, and low burnout in each dimension, using the cut-off values applicable for physicians (1), as follows: EE - low burnout $\leq 18$, moderate burnout 19 to 26 , high burnout $\geq 27$; DP - low burnout $\leq 5$, moderate burnout 6 to 9 , high burnout $\geq 10$; and PA high burnout $\leq 33$, moderate burnout 34 to 39 , and low burnout $\geq 40$ (inverse scale).

Mean patient enablement score and mean consultation duration were calculated for each physician. Enablement scores were divided into three groups as follows: low $\left(<25^{\text {th }}\right.$ percentile $)$, medium $\left(25^{\text {th }}\right.$ to $75^{\text {th }}$ percentile), and high ( $>75^{\text {th }}$ percentile).

Kruskal-Wallis test was used to test the differences in EE, DP, and PA between categorical variables. Spearman correlation was used to establish the relationship between EE, DP, and PA scores and numerical variables. Multiple regression analysis was used to identify factors associated with burnout levels. EE, DP, and PA overall scores were used as dependent variables. Predictor variables included physician's age, sex, marital status (married or other), children (yes/ no), educational/academic engagement (yes/no), type of employment (state-employed or self-employed), years at current position, average number of patients per day, average number of house calls per week, job satisfaction, mean physician-specific patient enablement score, and mean physician-specific duration of consultations.

$P$ value $<0.05$ was considered statistically significant. Software SAS 8.0.2 (SAS Institute Inc., Carry, NC, USA) was used for data analysis.

\section{RESULTS}

Of 350 invited physicians, 125 completed and returned physician and patient questionnaires (response rate $35.7 \%$ ). Of 6250 patients approached;
5527 patients provided questionnaires that could be used for statistical analysis (response rate $88.4 \%$ ).

The responding physicians' mean age \pm standard deviation (SD) was (46.0 \pm 7.0 ) years, with an average of (13.3 \pm 7.4$)$ years working at the current position. Most were women ( $N=102,81.6 \%)$ (Table 1). The responding physicians saw (49.2 \pm 9.8$)$ patients a day and made (5.0 \pm 3.6$)$ house calls a week. Twenty-four $(19.2 \%)$ physicians were engaged in an educational and/or academic activity (Table 1). Average job satisfaction score was 3.9 1.4 .

Mean EE score \pm standard deviation was $24.7 \pm 12.1$, DP 5.1 \pm 4.6 , and PA $40.3 \pm 5.9$. A total of $42.4 \%$ of physicians scored high for EE, $16.0 \%$ scored high for DP, and $15.2 \%$ scored high for PA burnout (Table 2).

Mean patient enablement scores at physician level ranged from 3.2 to 9.6, with an overall physicianspecific mean enablement score \pm SD of $6.6 \pm 1.2$. Enablement scores were normally distributed: 32 $(25.6 \%)$ physicians had mean enablement score in the bottom quartile $\left(<25^{\text {th }}\right.$ percentile, mean enablement score 3.2 to 5.8$), 63$ (50.4\%) between the bottom and top quartile $\left(25^{\text {th }}\right.$ to $75^{\text {th }}$ percentile, mean score 5.9 to $7.5)$, and $30(24.0 \%)$ in the top quartile $\left(>75^{\text {th }}\right.$ percentile, mean score 7.6 to 9.6).

Mean consultation duration ranged from $4.8 \mathrm{~min}$ to $22.4 \mathrm{~min}$, with an overall physician-specific average consultation duration of (11.6 \pm 3.3$) \mathrm{min}$.

The Kruskal-Wallis test did not reveal any statistically significant difference in EE, DP, and PA between subgroups of physicians in relation to sex, marital status, having children, being involved in an educational or academic activity, or type of employment.

Job satisfaction correlated significantly with all three burnout dimension scores; the average number of patients per day correlated with the EE score, and mean consultation duration correlated significantly with the PA score (Table 3).

Multiple regression analysis showed that job satisfaction and average number of patients per day significantly correlated with the EE score. Physician's age, number of years working at current workplace, and job satisfaction significantly correlated with the DP score. Being involved in educational or academic activity, number of years working at current workplace, and physician-specific mean consultation duration significantly correlated with the PA score (Table 4).

Distribution of low, moderate, and high EE, DP, or PA burnout did not correlate with the distribution of low, medium, and high physician-specific patient 
enablement scores nor did the presence of none, any, or all three burnout dimension correlate with patient enablement scores.

\section{DISCUSSION}

Our findings suggest that burnout is quite common in family physicians in Croatia. Compared to EGPRN global findings (11), our population being a part of that study, the proportion of family physicians with high EE burnout in Croatia is comparable to global rates (42.4\% vs. $43.0 \%$ ), while high DP and high PA burnout is lower in the Croatian arm $(16.0 \%$ and $15.2 \%$ in the Croatian arm vs. $35.3 \%$ and $32.0 \%$ in the EGPRN study, respectively). However, the 12 European countries included in the EGPRN burnout study show a considerable variation in burnout rates (11). Many European studies independent of EGPRN report lower burnout rates, just as ours does (5-9).

Burnout in physicians in our study was not associated with patient enablement and therefore with the quality of interpersonal care. Although somewhat unexpected, these results can be discussed from different perspectives. Patient enablement stems from patient-centred care (16). In a study by Howie et al. (23), physicians who rated their stress the highest practiced more patient-centred style in consultations. Similarly, Zantinge et al. (24) found that emotionally exhausted general practitioners (GPs) had longer consultations with their patients. In another study by the same authors (25), GPs discussed about psychological problems with their patients even when their workload was the heaviest. Ratanawongsa et al. (18) also found no association between physician burnout and patient-centredness or patients' ratings of satisfaction, confidence or trust. Similar results were reported by Orton et al. (17), who showed that higher depersonalisation scores were not associated with poorer patient ratings of doctors' interpersonal skills or a lower patient-centeredness rating.

While patient-centeredness and responding to patient needs may result in better patient-reported outcomes, it may also be associated with depletion of physician's own emotional reserves and burnout. Our study supports this thesis, as more years working at the current workplace (i.e. for the same population) correlated with higher DP and PA burnout. Personal factors such as setting high professional standards and sensitivity to patient expectations have previously been reported to increase the chance of developing burnout (2), so it does not seem unlikely that physicians who are providing good interpersonal quality of care might be susceptible to burnout.

Another reason why burnout in physicians was not associated with patient enablement could be related to patients' expectations. Patients' expectations have previously been reported as a key determinant of enablement (26). Consequently, patients who are used to a certain consulting style, although objectively of a doubtful quality, may see it acceptable simply because it is in line with their previous experience. Patients of burned-out physicians may therefore feel equally enabled as other patients as a result of their expectations. Clearly, the relationship between physician's psychological wellbeing and patientperceived physician performance is complex and needs further investigation.

One of the important findings in our study is that longer consultations contributed to physician's feeling of higher personal accomplishment. Longer consultations have been related to many positive patient-related quality outcomes (27-29) as well as reduced stress in general practitioners $(30,31)$, with the strongest effect in GPs who are patient-centred (31). Having sufficient time for consultation (which is closely related with the number of patients a physician sees every day) positively correlates with and is important in preserving doctor's psychological wellbeing.

Physicians' academic or educational activities correlated with their feeling of higher personal accomplishment. All our participants were full-time family physicians, and teaching medical students, interns, or trainees or involvement in research and academic work were additional workload. Nevertheless, this type of activities protected physicians against PA burnout, unlike seeing more patients. In a study by Lee et al. (32), continuing medical education (CME) of family physicians was recognised as a strategy to reduce stress on the job and was associated with lower levels of burnout. Our results have confirmed that educational or academic activities provide an opportunity to build one's professional self-esteem and contribute to higher job satisfaction as the strongest known predictor against burnout $(2,11,33)$. Intellectual stimulation predicted higher job satisfaction in Dutch medical specialists (33) and not being a member of a CME group doubled the likelihood of burnout in Danish GPs (34). In Israeli primary care physicians CME activities also positively correlated with job satisfaction and negatively with burnout (35). 
Participation in academic or educational activities is an opportunity to receive support from colleagues, which diminishes the family physician's sense of professional isolation. Australian GPs who considered leaving rural practices had fewer colleagues with whom to discuss professional issues (36), while the ones who chose to stay established personal and professional networks (37).

As expected, the strongest association in our study was the one between job satisfaction and EE or DP burnout. Job satisfaction has already been reported to protect against the adverse effects of work stress on mental health $(33,38)$ and against burnout $(2,11)$.

Higher level of depersonalisation in younger physicians in our study is in line with earlier reports $(2,39,40)$ and reflects the difficulties in balancing career, family life, and personal development of a young doctor. At the same time, higher level of depersonalisation and feeling of professional ineffectiveness was associated with more years working at the current position. Although there is a lot of evidence that interpersonal continuity of care contributes to therapeutic doctor-patient relationship and positive outcomes of care $(20,22,41,42)$, some negative emotional effects have also been recognised, such as frustration, boundary issues, and negative effects on personal life (43). Burnout rates in older surgeons in a study by Campbell et al. (40) were lower due to greater job satisfaction and perceived sense of control and autonomy in practice (40). One of the specific features of working as a family physician in a solo practice is that it is difficult to reduce workload or increase sense of control with age, which provides opportunity for burnout to grow insidiously with years in clinical practice.

No relationship between burnout and most of the other tested demographic characteristics suggests that all family physicians are vulnerable to burnout. Strategies aimed at preventing burnout should thus be addressed to all family physicians rather than certain groups at risk.

\section{Limitations of the study}

This study has several limitations. We achieved a response rate of $35.7 \%$ from our stratified sample of physicians, with a rather small proportion of practices with list sizes $\leq 1200$ patients. However, our analyses suggest that our respondents did not differ substantially in demographic (age, sex) and professional (vocational training) characteristics from the total population of physicians working in the family medicine service in
Croatia in 2002. The same is true for responding patients. A more detailed comparison between responders and non-responders has been published earlier (20).

It is possible that physicians who chose not to take part in the study may have scored differently on the MBI-HSS and influence the reported burnout rates in physicians. In addition, self-reporting about burnout and patient enablement, and the cross-sectional design of the study call for cautious interpretation.

\section{CONCLUSIONS}

Burnout is common among family physicians in Croatia and is not associated with patient enablement. In other words, it does not affect the quality of interpersonal care.

Job satisfaction, educational or academic activities, and sufficient consultation time seem to protect against burnout. Years of providing long-term care for the same population appear to increase the risk of depersonalisation and feelings of professional ineffectiveness in physicians. Further research should address these factors in order to explore and develop effective intervention programmes.

\section{Acknowledgments}

We would like to thank the family physicians who participated in the study and completed the questionnaires and the Croatian Institute for Health Insurance for providing the 2002 physician database that served as our sampling source. We would also like to thank Professor Davor Ivanković for his valuable help in sampling. This cross-sectional study was a part of the two concurrent research projects: a research project no. 0108331, sponsored by the Croatian Ministry of Science, Education, and Sports, and a research project entitled European General Practice Research Network (EGPRN) Burnout Study, supported jointly by EGPRN and the European section of the World Organization of National Colleges, Academies and Academic Associations of General Practitioners/Family Physicians (WONCA).

A part of the preliminary results of this study was presented at the $6^{\text {th }}$ EQuiP Invitational Conference Value for money in general practice - management and public trust, Copenhagen, Denmark, April 7-9, 2011, and has been included in the conference proceedings in the form of an abstract entitled "Burnout in general practitioners in Croatia - does it affect interpersonal quality of care?". 


\section{REFERENCES}

1 Maslach C, Jackson SE, Leiter MP. Maslach Bunout Inventory Manual. $3^{\text {rd }}$ ed. Mountain View (CA): Consulting Psychologists Press; 1996.

2 Maslach C, Schaufeli WB, Leiter MP. Job burnout. Annu Rev Psych 2001;52:397-422.

3 Leiter MP, Frank E, Matheson TJ. Demands, values and burnout: relevance for physicians. Can Fam Physician 2009;55:1224-5

4 Klemenc-Ketiš Z, Kersnik J, Ojsteršek J. Perceived difficulties in managing ethical problems in family practice in Slovenia: cross-sectional study. Croat Med J 2008;49:799806. doi: $10.3325 / \mathrm{cmj} .2008 .49 .799$

5 Goehring C, Bouvier Gallacchi M, Kuenzi B, Bovier P. Psychosocial and professional characteristics of burnout in Swiss primary care practitioners: a cross sectional survey. Swiss Med Wkly 2005;135:101-8.

6 Grassi L, Magnani K. Psychiatric morbidity and burnout in the medical profession: an Italian study of general practitioners and hospital physicians. Psychother Psychosom 2000;69:329-34. doi: 10.1159/000012416

7 Cathébras P, Begon A, Laporte S, Bois C, Truchot D. [Burnout among French general practitioners, in French]. Presse Med 2004;33:1569-74.

8 Kirwan M, Armstrong D. Investigation of burnout in a sample of British general practitioners. Br J Gen Pract 1995;45:25960 .

9 Marcelino G, Cerveira JM, Carvahalo I, Costa I, Lopes JA, Calado M, Pedro M-VNE. Burnout levels among Portugese family doctors: a nationwide survey. BMJ Open 2012;2: e001050. doi:10.1136/bmjopen-2012-001050

10 Selič P, Stegne-Ignjatović T, Klemenc-Ketiš Z. Burnout among Slovenian family medicine trainees: a cross sectional study. Zdrav Vestn 2012;81:218-24.

11 Soler JK, Yaman H, Esteva M, Dobbs F, Asenova RS, Katic M, Ozvacic Z, Desgranges JP, Moreau A, Lionis C, Kotányi P, Carelli F, Nowak PR, de Aguiar Sá Azeredo Z, Marklund E, Churchill D, Ungan M; European General Practice Research Network.Burnout Study Group. Burnout in European family doctors: the EGPRN study. Fam Pract 2008;25:245-65. doi:10.1093/fampra/cmn038

12 West CP, Huschka MM, Novotny PJ, Sloan JA, Kolars JC, Habermann TM, Shanafelt TD. Association of perceived medical errors with resident distress and empathy. A prospective longitudinal study. JAMA 2006;296:1071-8.

13 Shanafelt TD, Bradely KA, Wipf JE, Back AL. Burnout and self-reported patient care in an internal medicine residency program. Ann Intern Med 2002;136:358-67.

14 Fahrenkopf AM, Sectish TC, Barger LK, Sharek PJ, Lewin D, Chiang VW, Edwards S, Wiedermann BL, Landrigan CP. Rates of medication errors among depressed and burned-out residents: prospective cohort study. BMJ 2008;336:488-91. doi: 10.1136/bmj.39469.763218

15 Campbell SM, Roland MO, Buetow SA. Defining quality of care. Soc Sci Med 2000;51:1611-25. doi: 10.1016/S02779536(00)00057-5

16 Howie JGR, Heaney DJ, Maxwell M. Quality, core values and the general practice consultation: issues of definition, measurment and delivery. Fam Pract 2004;21:458-68. doi: 10.1093/fampra/cmh419
17 Orton P, Orton C, Pereira Gray D. Depersonalised doctors: a cross sectional study of 564 doctors, 760 consultations and 1876 patient reports in UK general practice. BMJ Open 2012;2:e000274. doi: 10.1136/bmjopen-2011-000274

18 Ratanawongsa N, Roter D, Beach MC, Laird SL, Larson SM, Carson KA, Cooper LA. Physician burnout and patientphysician communication during primary care encounters. J Gen Intern Med 2008;23:1581-8. doi: 10.1007/s11606-0080702-1

19 Croatian National Institute of Public Health. [Croatian Health Service Yearbook 2002, in Croatian]. Zagreb: Hrvatski zavod za javno zdravstvo; 2003.

20 Ožvačić Adžić Z, Katić M, Kern J, Lazić D, Cerovečki Nekić V, Soldo D. Patient, physician, and practice characteristics related to patient enablement in general practice in Croatia: cross-sectional survey study. Croat Med J 2008;49:81323.

21 Yaman H, Soler JK. The job related burnout questionnaire. A multinational pilot study. Austral Fam Physician 2002;31:1055-6.

22 Howie JGR, Heaney DJ, Maxwell M, Walker JJ, Freeman GK, Rai H. Quality at general practice conultations: crosssectional survey. BMJ 1999;319:738-43. doi: 10.1136/ bmj.319.7212.738

23 Howie JGR, Hopton JL, Heaney DJ, Porter AMD. Attitudes to medical care, the organization of work, and stress among general practitioners. Br J Gen Pract 1992;42:181-5.

24 Zantinge EM, Verhaak PFM, de Bakker DH, van der Meer K, Bensing JM. Does burnout among doctors afect their involvement in patients' mental health problems? A study of videotaped consultations. BMC Fam Pract 2009;10:60. doi:10.1186/1471-2296-10-60

25 Zantinge EM, Verhaak PFM, de Bakker DH, Kerssens J, van der Meer K, Bensing JM. The workload of general practitioners does not affect their awareness of patients' psychological problems. Patient Educ Couns 2007;67:93-9. doi: 10.1016/j.pec.2007.02.006

26 Mercer SW, Reilly D, Watt GC. The importance of empathy in the enablement of patients attending the Glasgow Homoeopathic Hospital. Br J Gen Pract 2002;52:901-5.

27 Freeman GK, Horder JP, Howie JGR, Hungin AP, Hill AP, Shah NC, Wilson A. Evolving general practice consultation in Britain: issues of length and context. BMJ 2002;324: 8802. doi: $10.1136 /$ bmj. 324.7342 .880

28 Wilson A, Childs S. The relationship between consultation length, process and outcomes in general practice: a systematic review. Br J Gen Pract 2002;52:1012-20.

29 Howie JGR, Porter AMD, Heaney DJ, Hopton JL. Long to short consultation ratio: a proxy measure of quality of care for general practice. Br J Gen Pract 1991;41:48-54.

30 Wilson A, McDonald P, Hayes L, Cooney J. Longer booking intervals in general practice: effects on docotrs' stress and arousal. Br J Gen Pract 1991;41:184-7.

31 Howie JGR, Hopton JL, Heaney DJ, Porter AMD. Attitudes to medical care, the organization of work, and stress among general practitioners. Br J Gen Pract 1992;42:181-5.

32 Lee FJ, Stewart M, Brown JB. Stress, burnout and strategies for reducing them. Can Fam Physician 2008;54:234-5.

33 Visser MRM, Smets EMA, Oort FJ, de Haes HCJM. Stress, sastisfaction and burnout among Dutch medical specialists. CMAJ 2003;168:271-5. 
34 Brøndt A, Sokolowski I, Olesen F, Vedsted P. Continuing medical education and burnout among Danish GPs. Br J Gen Pract 2008;58:15-9. doi: 10.3399/bjgp08X263767

35 Kushnir T, Cohen AH, Kitai E. Continuing medical education and primary physician's job stress, burnout and dissatisfaction. Med Educ 2000;34:430-6.

36 Gardiner M, Sexton R, Durbridge M, Garrard K. The role of psychological well-being in retaining rural general practitioners. Aust J Rural Health 2005;13:149-55. doi: 10.1111/j.1440-1854.2005.00677.x

37 Hays R, Wynd S, Veitch C, Crossland L. Getting the balance right? GPs who chose to stay in rural practice. Aust J Rural Health 2003;11:193-8.

38 Bovier PA, Arigoni F, Schneider M, Gallacchi MB Relationships between work satisfaction, emotional exhaustion and mental health among Swiss primary care physicians. Eur J Public Health 2009:19:611-7. doi: 10.1093/ eurpub/ckp056
39 Al-Dubai SA, Rampal KG. Prevalence and associated factors of burnout among doctors in Yemen. J Occup Health 2010;52:58-65.

40 Campbell DA Jr, Sonnad SS, Eckhauser FE, Campbel KK, Greenfield JG. Burnout among American surgeons. Surgery 2001;130:696-702

41 Saultz JW. Lochner J. Interpersonal continuity of care and care outcomes: a critical review. Ann Fam Med 2005;3:15966. doi: 10.1370/afm.285

42 Schers H, van den Hoogen H, Bor H, Grol R, van den Bosch R. Familiarity with a GP and patients' evaluations of care. A cross-sectional study. Fam Pract 2005;22:15-9. doi: 10.1093/ fampra/cmh721

43 Schultz K, Delva D, Kerr J. Emotional effects of continuity of care on family physicians and the therapeutic relationship. Can Fam Physician 2012;58:178-85. 


\section{Sažetak}

\section{SINDROM IZGARANJA MEĐU LIJEČNICIMA OBITELJSKE MEDICINE U HRVATSKOJ - POSTOJI LI POVEZANOST S KVALITETOM KOMUNIKACIJSKE SKRBI?}

Povezanost sindroma izgaranja liječnika i kvalitete skrbi nije potpuno jasna. Cilj rada bio je istražiti učestalost sindroma izgaranja u liječnika obiteljske medicine (LOM) u Hrvatskoj te povezanost sindroma izgaranja i obilježja liječnika i njegove prakse te osposobljenosti bolesnika kao mjere ishoda konzultacije.

Provedeno je presječno istraživanje na nacionalnom stratificiranom slučajnom uzorku od 350 LOM koji su prikupili podatke od 50 odraslih bolesnika tijekom 50 susljednih konzultacija. Za bolesnike su prikupljeni podaci o osposobljenosti bolesnika (Upitnik za procjenu osposobljenosti bolesnika, PEI), duljini konzultacije, a za liječnike podaci o demografskim i profesionalnim značajkama, opterećenju poslom, zadovoljstvu poslom, prisutnosti sindroma izgaranja na poslu (Maslach Burnout Inventory - MBI-HSS). Vrijednosti MBI-HSS analizirane su u tri dimenzije: emocionalna iscrpljenost (EI), depersonalizacija (DP) i osobno postignuće (OP).

Među 125 liječnika, EI visokog stupnja zabilježena je kod 42,4 \%, DP visokog stupnja kod 16,0 \% te OP visokog stupnja kod 15,2 \% liječnika. U regresijskoj analizi visoke vrijednosti EI su predviđali manje zadovoljstvo poslom i veći broj bolesnika dnevno. Visoke vrijednosti DP su predviđali manje zadovoljstvo poslom, više godina na sadašnjem radnom mjestu i mlađa dob. Niske vrijednosti OP su predviđale izostanak sudjelovanja u nastavnim ili akademskim aktivnostima, kraće konzultacije te više godina na sadašnjem radnom mjestu $(P<0.05$ za svaki).

Sindrom izgaranja prisutan je među LOM u Hrvatskoj. Nismo utvrdili povezanost sindroma izgaranja liječnika i osposobljenosti bolesnika, odnosno prisutnost sindroma izgaranja nije bila povezana s kvalitetom komunikacijske skrbi. Zadovoljstvo poslom, sudjelovanje u nastavnim ili akademskim aktivnostima te dostatno vrijeme konzultacije mogli bi imati zaštitni učinak u nastanku sindroma izgaranja u liječnika.

KLJUČNE RIJEČI: kvaliteta zdravstvene skrbi, obiteljska medicina, osposobljenost bolesnika

\section{CORRESPONDING AUTHOR:}

Zlata Ožvačić Adžić

University of Zagreb, School of Medicine

"Andrija Štampar" School of Public Health

Department of Family Medicine

Rockefellerova 4, 10000 Zagreb, Croatia

E-mail: zlata.ozvacic@mef.hr 